\title{
Potassic and nitrogen fertilization in a modern hybrid of sorghum for biomass production cultivated in an Oxisol
}

\author{
Franciele de Freitas Silva, Thomas Jefferson Cavalcante, Kassia de Paula Barbosa, Gustavo Castoldi*, \\ Mariângela Brito Freiberger, Fabiano Guimarães Silva
}

Goiano Federal Institute. Rio Verde, GO, Brazil

*Corresponding author: gustavo.castoldi@ifgoiano.edu.br

\begin{abstract}
Biomass sorghum [Sorghum bicolor (L.)] is a promising option for the supply of dedicated biomass for energy cogeneration in Brazil. However, it is still necessary to better understand gaps around the nutrient requirement and fertilization management, especially for modern materials. The aim of this study was to evaluate the effect of nitrogen (N) and potassium (K) doses on dry matter (DM) and nutrient accumulation in a modern hybrid of biomass sorghum cultivated in an Oxisol. For that, two separate trials were carried out with the hybrid Palo Alto 2562, grown in 2015/16 summer season in the central-western region of Brazil. Both trials were carried out in a randomized block design with four replicates and five doses: 0, 70, 140, 210 and $280 \mathrm{~kg} \mathrm{ha}^{-1}$ (of N or K). The hybrid Palo Alto 2562 responded positively to $\mathrm{N}$ fertilization. The DM production and $\mathrm{N}$ accumulation hybrid of Palo Alto 2562 was increased as $\mathrm{N}$ fertilization added, reaching, respectively, values of $24.6 \mathrm{Mg} \mathrm{ha}^{-1}$ and $206 \mathrm{~kg} \mathrm{ha}^{-1}$ at dose of $280 \mathrm{~kg} \mathrm{ha-1} \mathrm{N}$. Also, in order to avoid depletion of $\mathrm{N}$ levels in the soil we required a fertilization of at least $140 \mathrm{~kg} \mathrm{ha}^{-1} \mathrm{~N}$. The Palo Alto 2562 hybrid has a high absorption capacity of $\mathrm{K}$, which is the most absorbed nutrient by the plant, reaching values of $316 \mathrm{~kg} \mathrm{ha}^{-1}$. However, in this study due to high levels of $\mathrm{K}$ in the soil and high $\mathrm{K}$ saturation in $\mathrm{CEC}$, the $\mathrm{K}$ fertilization may be not necessary to produce sorghum biomass.
\end{abstract}

Keywords: Bioenergy, dedicated biomass, plant nutrition, nutrient export.

\section{Introduction}

The interest in obtaining energy through the production of dedicated biomass has increased in several countries, such as the United States, China, Italy and Brazil (Pannacci and Bartolini, 2016; Heitman et al., 2017; Meki et al., 2017; Tang et al., 2018). These countries share the interest of cultivating biomass sorghum (Sorghum bicolor L.) due to its great potential to produce raw material, as well as the fact that biomass sorghum presents interesting cultivation characteristics such as high water use efficiency and drought tolerance besides a chemical composition with high energy efficiency (Rooney et al., 2007).

New cultivation technologies and genotypes that are more productive and adapted to the edaphoclimatic conditions have favored the cultivation of sorghum in Brazil (Silva et al., 2018; Almeida et al., 2019). However, there is no wellestablished nutrient recommendation for it to express its full productive potential, with some gaps for adequate nutrient management (Rego et al., 2003; Rooney et al., 2007; Wight et al., 2012). Among the nutritional aspects, nitrogen (N) and potassium (K) are the most demanded nutrients for the production of biomass sorghum (Santos et al., 2014). This requirement may be even greater in more modern hybrids, mainly due to the greater potential for biomass production. A fertilization experiment of two biomass sorghum varieties (CMSXS 7020 and CMSXS 652) was performed in Sete Lagoas, MG, Brazil. The average extraction of $\mathrm{N}$, phosphorus $(\mathrm{P}), \mathrm{K}$, calcium (Ca) and magnesium $(\mathrm{Mg})$ was $7.6,0.8,10.8$, 3.6 and $2.5 \mathrm{~kg}$, respectively, for each tone of biomass produced (Santos et al., 2015). In the same trial, the maximum dry matter yield (DM) was $33.94 \mathrm{Mg} \mathrm{ha}^{-1}$, obtained by CMSXS 652 variety fertilized with $80 \mathrm{~kg} \mathrm{ha}^{-1}$ of $\mathrm{N}$ and $180 \mathrm{~kg} \mathrm{ha}^{-1}$ of $\mathrm{K}_{2} \mathrm{O}$, representing an extraction of $242 \mathrm{~kg}$ ha ${ }^{-1}$ of $\mathrm{N}, 32 \mathrm{~kg} \mathrm{ha}^{-1}$ of $\mathrm{P}$ and $298 \mathrm{~kg} \mathrm{ha}^{-1}$ of K (Santos et al., 2015). In an absorption accumulation curve experiment, the hybrid Palo Alto 2562 (fertilized with $198 \mathrm{~kg} \mathrm{ha}^{-1}$ of $\mathrm{N}$ and $285 \mathrm{~kg} \mathrm{ha}^{-1}$ of $\mathrm{K}_{2} \mathrm{O}$ ) has uptaken $289 \mathrm{~kg} \mathrm{ha}^{-1}$ of $\mathrm{N}, 38 \mathrm{~kg} \mathrm{ha}^{-1}$ of $\mathrm{P}$ and $447 \mathrm{~kg} \mathrm{ha}^{-1}$ of $\mathrm{K}$ to produce $24.43 \mathrm{Mg} \mathrm{ha}^{-1}$ of DM (Cavalcante et al., 2018).

Nitrogen has a key role in the chlorophyll molecule, as well as it is one of the responsible for the production of leaf area and regulation of the photosynthetic rate, being fundamental for the photosynthetic apparatus of the plant, which may reflect on the biomass production (Olson et al., 2013; Ameen et al., 2017; Tang et al., 2018). Potassium can 
be related to the increase of resistance to lodging in plants due to its importance for the stem stiffness (Castoldi et al., 2011; Júlio et al., 2016). So, a better understanding of biomass sorghum response to $\mathrm{N}$ and $\mathrm{K}$, particularly for new materials with a high demand for nutrients, is a key factor for the success and expansion of its cultivation in Brazil. In this context, the aim of this study was to evaluate the biometric parameters, dry matter production and the accumulation of nutrients by a modern hybrid of biomass sorghum cultivated in an Oxisol and as affected by $\mathrm{N}$ and $\mathrm{K}$ fertilization.

\section{Results}

Nutrients accumulation, biometric parameters and dry matter production in Nitrogen trial

Only the accumulation of manganese $(\mathrm{Mn})$ in the shoot part of the biomass sorghum was not influenced by the $\mathrm{N}$ doses (Table 2). On the other hand, the accumulation of $\mathrm{P}, \mathrm{Ca}$, sulfur (S), copper $(\mathrm{Cu})$ and zinc $(\mathrm{Zn})$ linearly increased with increasing $\mathrm{N}$ doses. In the particular case of DM and $\mathrm{N}$ (Figure 1), the highest accumulation also occurred at the highest dose of $\mathrm{N}\left(280 \mathrm{~kg} \mathrm{ha}^{-1}\right)$. Other nutrients, such as $\mathrm{K}$, $\mathrm{Mg}$, iron (Fe) and boron (B), presented a quadratic behavior forming a parabola with the vertex facing downward, with its minimum accumulation occurring at the calculated doses of $133.9 ; 72.5 ; 85.2$ and $121.4 \mathrm{~kg} \mathrm{ha}^{-1}$ of $\mathrm{N}$, respectively.

The accumulation of $\mathrm{N}$ in the shoot part of the biomass sorghum was linearly increased as the dose of $\mathrm{N}$ provided in the fertilization increased from $62.1 \mathrm{~kg} \mathrm{ha}^{-1}$ to $206.5 \mathrm{~kg} \mathrm{ha}^{-1}$ at doses 0 and $280 \mathrm{~kg} \mathrm{ha}^{-1}$, respectively (Figure $1 \mathrm{~A}$ ), showing an increase of 3.3 times. Following accumulation of $\mathrm{N}$, the $\mathrm{DM}$ accumulation rose from $14.5 \mathrm{Mg} \mathrm{ha}^{-1}$ to $24.6 \mathrm{Mg} \mathrm{ha}^{-1}$ at at dose of 0 and $280 \mathrm{~kg} \mathrm{ha}^{-1} \mathrm{~N}$, respectively (Figure 1B), an increase of $69.4 \%$. In the maximum DM production, the accumulation (in the shoot) of $\mathrm{P}, \mathrm{K}, \mathrm{Ca}, \mathrm{Mg}$ and $\mathrm{S}$ was 34.5, 273.2, 233.6, 105.8 and $9.1 \mathrm{~kg} \mathrm{ha}^{-1}$, respectively (Table 2). For $\mathrm{Cu}, \mathrm{Fe}, \mathrm{Mn}, \mathrm{Zn}$ and $\mathrm{B}$ the values were 208, 3,942, 283, 862 and $179 \mathrm{~g} \mathrm{ha}^{-1}$, respectively (Table 2 ).

Nitrogen doses did not interfere with the height and stem diameter of the biomass sorghum plants, which at the time of harvest showed means of $4.87 \mathrm{~m}$ and $1.98 \mathrm{~cm}$, respectively. In the simplified balance of $\mathrm{N}$ in the system, doses 0 and $70 \mathrm{~kg} \mathrm{ha}^{-1}$ of $\mathrm{N}$ resulted in a negative balance (Figure 2), which means that under these conditions the plant has uptaken (only in the shoot part) more $\mathrm{N}$ than those supplied via fertilization. In this study, it was evident that $\mathrm{N}$ doses from $140 \mathrm{~kg} \mathrm{ha}^{-1}$ are required to meet the crops need.

\section{Nutrients accumulation, biometric parameters and dry matter production in Potassium trial}

The analysis of variance revealed significant effects of $K$ doses on DM production and nutrient accumulation, except for the accumulation of $\mathrm{Mg}$ and $\mathrm{B}$ (Table 3 ). The nutrients $\mathrm{P}$, $\mathrm{Ca}$ and $\mathrm{S}$ showed a linear decreasing behavior, with lower values of accumulation as $\mathrm{K}$ doses increased. The other nutrients responded quadratically, with $\mathrm{K}$ and Fe presenting the maximum accumulation point estimated at the doses of 134.8 and $76.2 \mathrm{~kg} \mathrm{ha}^{-1}$ of $\mathrm{K}$, respectively.

The absorption of $K$ had the maximum estimated accumulation of $316.2 \mathrm{~kg} \mathrm{ha}^{-1}$ at the dose of $134.8 \mathrm{~kg} \mathrm{ha}^{-1} \mathrm{~K}$ (Figure $3 \mathrm{~A})$. On the other hand, the accumulation of DM presented a linear decreasing behavior (Figure 3B), unlike the $N$ trial, in which the behavior was linearly increased (Figure 1B). Thus, for the $\mathrm{K}$ trial, the highest accumulation of DM (21.47 $\mathrm{Mg} \mathrm{ha}^{-1}$ ) was occurred in the absence of $\mathrm{K}$ fertilization. In this condition, the accumulation (in the shoot) of N, P, Ca, Mg and S was 149.5, 25.5, 190.5, 56.9 and $14.7 \mathrm{~kg} \mathrm{ha}^{-1}$, respectively (Table 3 ). For $\mathrm{Cu}, \mathrm{Fe}, \mathrm{Mn}, \mathrm{Zn}$ and $\mathrm{B}$ this value was, respectively, 195, 2,427, 395, 618 and $249 \mathrm{~g}$ $\mathrm{ha}^{-1}$ (Table 3).

The $\mathrm{K}$ fertilization did not significantly affect the height and stem diameter of the biomass sorghum plants, which at the time of harvest presented $4.84 \mathrm{~m}$ and $1.96 \mathrm{~cm}$, respectively. The simplified balance of $K$ in the system (Figure 4 ) indicates that only the dose of $280 \mathrm{~kg} \mathrm{ha}^{-1}$ presented a positive balance of $\mathrm{K}$, with a surplus of approximately $104 \mathrm{~kg} \mathrm{ha}^{-1}$. In all the other doses $\left(0,70,140\right.$ and $210 \mathrm{~kg} \mathrm{ha}^{-1}$ - Figure 4), the amount of $\mathrm{K}$ accumulated in the shoot of plants was higher than the amount of $\mathrm{K}$ provided by $\mathrm{K}$ fertilization, so that the $K$ balance was negative (Figure 4 ).

\section{Discussion}

The results regarding the average plant height $(4.85 \mathrm{~m})$ in the $\mathrm{N}$ trial were close to that obtained in trials with the variety CMSXS 7015 cultivated in four spacing and populations in the $2012 / 2013$ and $2013 / 2014$ crop years, with mean values of plant height of 5.24 and $4.83 \mathrm{~m}$, respectively (May et al., 2015). However, agronomic characteristics of biomass sorghum such as plant height, stem diameter and dry matter can vary due to several factors related to the hybrid, soil nutrient availability, climatic conditions, area history and management practices (May et al., 2015; Santos et al., 2015; Pannacci and Bartolini, 2016).

The increase in DM production due to the increase in $\mathrm{N}$ fertilization (Figure 1B) demonstrates the important role that $\mathrm{N}$ has in the vegetative growth of biomass sorghum. Synergistic effect of $\mathrm{N}$ doses on sorghum production was also reported in Texas, on a clayey Pulman soil, with DM values of 12.1 and $18.2 \mathrm{Mg} \mathrm{ha}^{-1}$, respectively, found for TAMX08001 and TAM09024 under different $\mathrm{N}$ doses and irrigation levels (Hao et al., 2014).

Dry matter yield for sorghum biomass was directly related to the increase of $\mathrm{N}$ doses (Figure 1B), so the difference between doses 0 and $280 \mathrm{~kg} \mathrm{ha}^{-1} \mathrm{~N}$ was $10.1 \mathrm{Mg} \mathrm{ha}^{-1}$ corresponding to an increase of $69.4 \%$. In this condition of highest DM production ( $24,6 \mathrm{Mg}^{-1}$ with $280 \mathrm{~kg} \mathrm{ha}^{-1} \mathrm{~N}$ ), the nutrient accumulation in the shoot occurred the following order: $\mathrm{K}>\mathrm{Ca}>\mathrm{N}>\mathrm{Mg}>\mathrm{P}>\mathrm{S}>\mathrm{Fe}>\mathrm{Zn}>\mathrm{Mn}>\mathrm{Cu}>\mathrm{B}$. The variation in DM yield shows that the production potential (in the higher $\mathrm{N}$ doses) is close to that presented by other modern hybrids such as biomass sorghum 133Syngenta, which produced between 18.1 and $25.0 \mathrm{Mg} \mathrm{ha}^{-1}$ of $\mathrm{DM}$ when grown under two $\mathrm{N}$ doses and two irrigation levels 
Table 1. Soil pH, organic matter $(\mathrm{OM})$, phosphorus $(\mathrm{P})$, potassium $(\mathrm{K})$, calcium $(\mathrm{Ca})$, magnesium $(\mathrm{Mg})$, potential acidity $(\mathrm{H}+\mathrm{Al})$, cation exchange capacity (CEC) and base saturation (V), in the layers of 0.0-0.1, 0.1-0.2 and 0.2-0.4 $\mathrm{m}$ in the soil at the experimental area. Rio Verde, GO, Brazil.

\begin{tabular}{|c|c|c|c|c|c|c|c|c|c|}
\hline Depth & $\mathrm{pH}$ & OM & $P$ & $\mathrm{~K}$ & $\mathrm{Ca}$ & $\mathrm{Mg}$ & $\mathrm{H}+\mathrm{Al}$ & CEC & $\mathrm{V}$ \\
\hline (m) & $\mathrm{CaCl}_{2}$ & $\mathrm{~g} \mathrm{dm}^{-3}$ & $\mathrm{mg} \mathrm{dm}^{-3}$ & $-\cdots$ & --- & c dm & 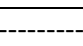 & & $\%$ \\
\hline $0.0-0.1$ & 5.48 & 39.8 & 21.5 & 0.7 & 2.6 & 0.9 & 4.5 & 8.7 & 49 \\
\hline $0.1-0.2$ & 4.98 & 32.7 & 14.0 & 0.3 & 1.6 & 0.6 & 5.1 & 7.7 & 33 \\
\hline $0.2-0.4$ & 5.19 & 31.4 & 12.6 & 0.3 & 1.5 & 0.5 & 4.1 & 6.4 & 36 \\
\hline
\end{tabular}

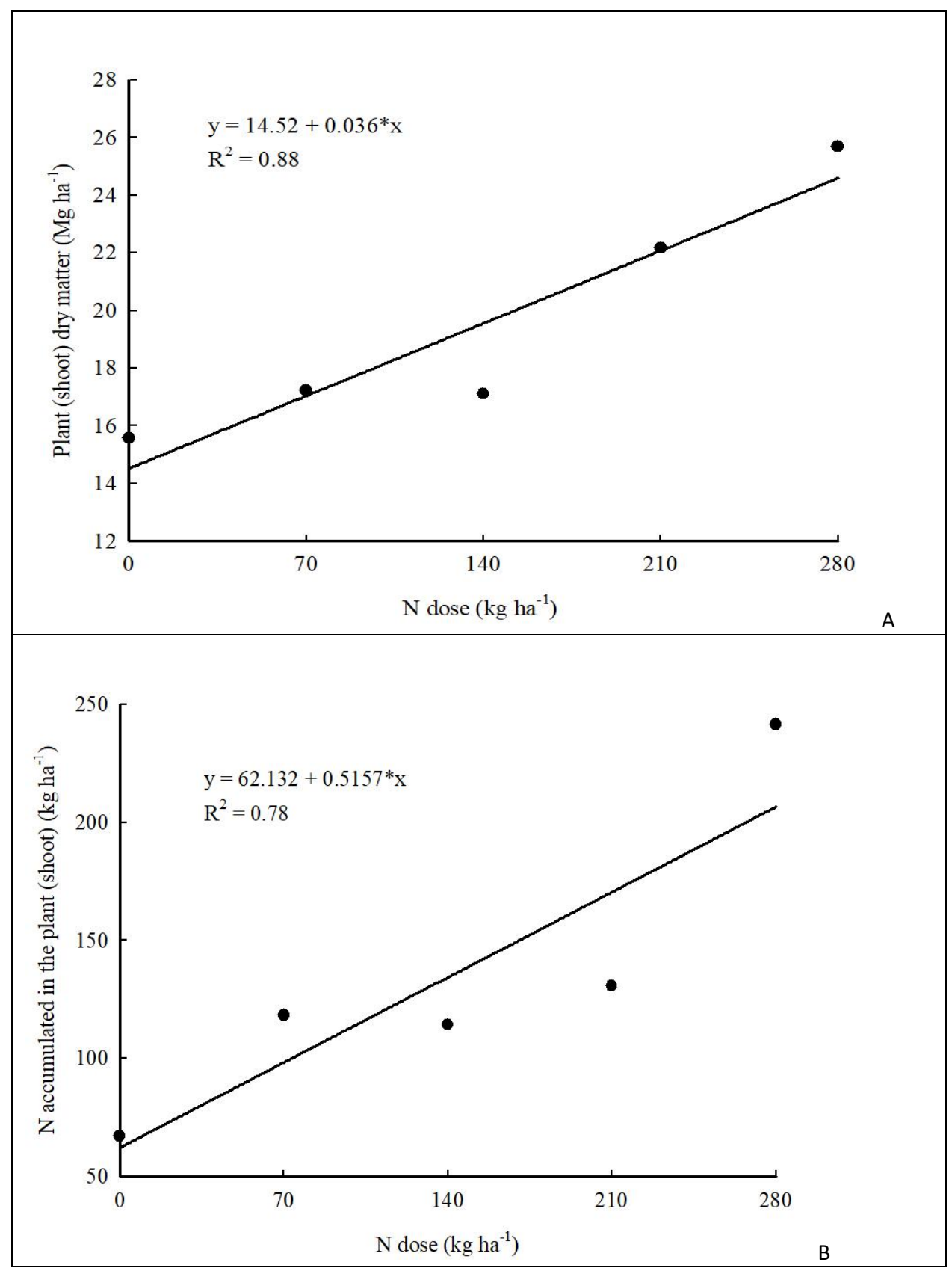

Fig 1. Total shoot dry matter (A) and nitrogen (N) accumulated in the shoot dry matter (B) of biomass sorghum (hybrid Palo Alto 2562) cultivated in an Oxisol and as affected by K doses. Rio Verde, GO, Brazil. 
Table 2. Accumulation of dry matter (DM) and macro and micronutrients in the shoot part of the biomass sorghum (hybrid Palo Alto 2562), at the harvest stage and as a function of nitrogen (N) doses. Rio Verde, GO, Brazil.

\begin{tabular}{|c|c|c|c|c|c|c|c|}
\hline \multirow{2}{*}{ Variable } & \multicolumn{5}{|c|}{$\mathrm{N}$ dose $\left(\mathrm{kg} \mathrm{ha}^{-1}\right)$} & \multirow{2}{*}{$\mathrm{F}$} & \multirow{2}{*}{ Equation } \\
\hline & 0 & 70 & 140 & 210 & 280 & & \\
\hline & \multicolumn{7}{|c|}{ 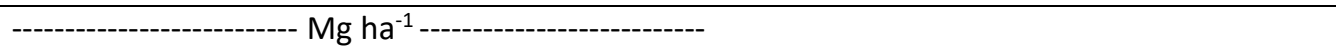 } \\
\hline DM & 15.57 & 17.23 & 17.10 & 22.17 & 25.70 & $* *$ & $y=14.513+0.0360 x$ \\
\hline & & & $\mathrm{kg} \| \mathrm{d}$ & 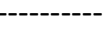 & ----- & & \\
\hline $\mathrm{N}$ & 67.00 & 118.3 & 114.3 & 130.7 & 241.3 & $* *$ & $y=62.133+0.5157 x$ \\
\hline $\mathrm{P}$ & 15.33 & 25.33 & 18.00 & 34.00 & 34.00 & $* *$ & $y=16.133+0.0657 x$ \\
\hline $\mathrm{K}$ & 277.3 & 154.7 & 250.0 & 183.7 & 280.0 & $* *$ & $y=261.74-1.079 x+0.0040 x^{\wedge} 2$ \\
\hline $\mathrm{Ca}$ & 137.7 & 157.3 & 156.0 & 209.3 & 243.7 & $* *$ & $y=128.00+0.3771 x$ \\
\hline $\mathrm{Mg}$ & 50.33 & 61.00 & 55.33 & 62.00 & 110.67 & $*$ & $y=56.152-0.1867 x+0.0013 x^{\wedge} 2$ \\
\hline$S$ & 8.33 & 11.00 & 9.33 & 11.00 & 12.33 & $* *$ & $y=8.800+0.0011 x$ \\
\hline $\mathrm{Cu}$ & 113.7 & 111.0 & 113.3 & 212.3 & 205.0 & * & $y=94.267+0.4057 x$ \\
\hline $\mathrm{Fe}$ & 1812 & 2074 & 1767 & 2108 & 4174 & * & $y=2042.4-10.577 x+0.0620 x^{\wedge} 2$ \\
\hline $\mathrm{Mn}$ & 213.3 & 272.3 & 267.3 & 316.0 & 344.3 & ns & $y=282.66$ \\
\hline $\mathrm{Zn}$ & 297.0 & 622.7 & 402.0 & 697.3 & 936.7 & $* *$ & $y=320.33+1.9343 x$ \\
\hline $\mathrm{B}$ & 116.7 & 112.0 & 65.00 & 67.00 & 201.0 & $* *$ & $y=134.22-1.1553 x+0.0047 x^{\wedge} 2$ \\
\hline
\end{tabular}

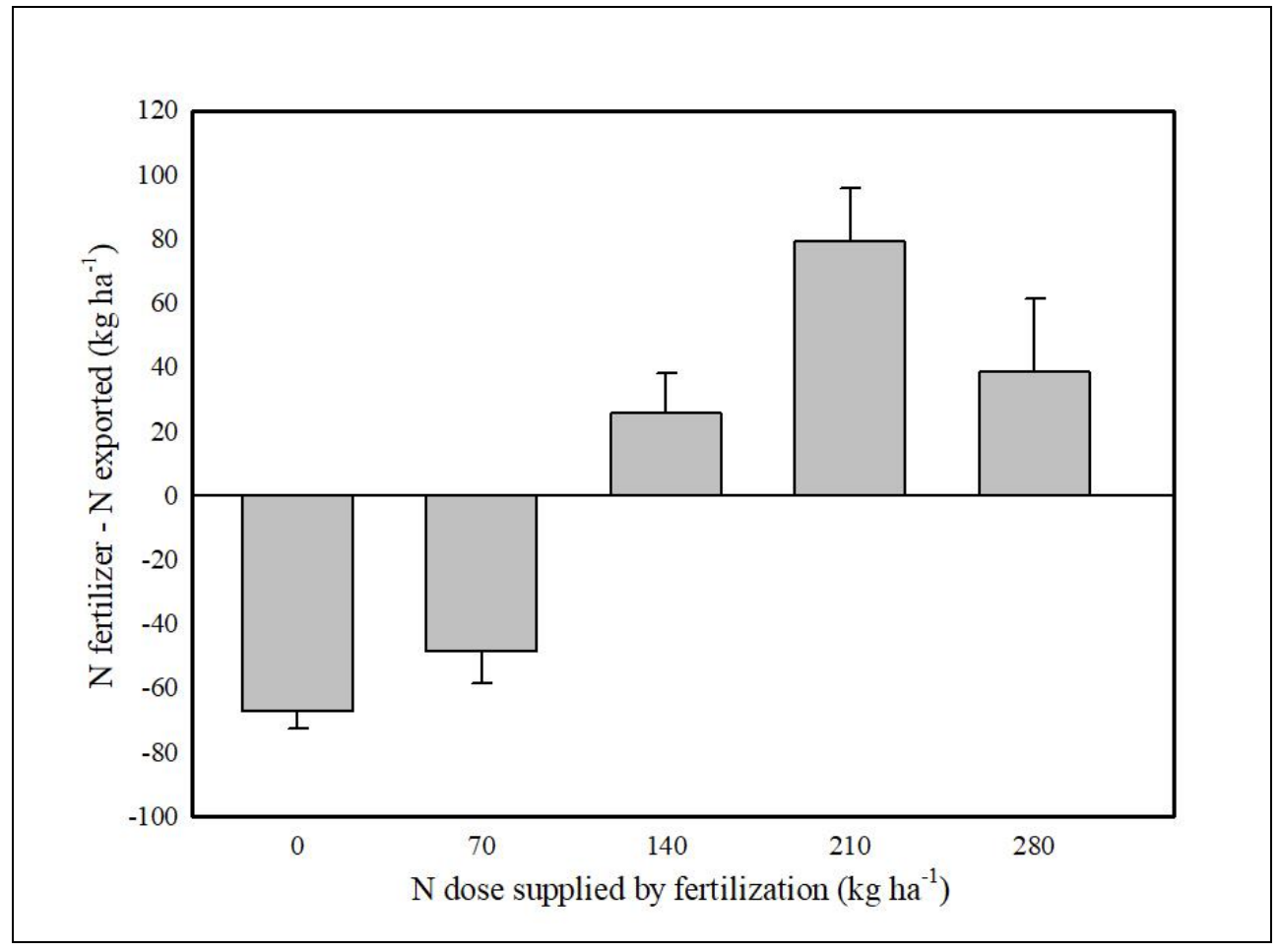

Fig 2. Simple balance between the amount of nitrogen $(\mathrm{N})$ supplied by the fertilizer ( $\mathrm{N}$ dose) and the amount of $\mathrm{N}$ accumulated in the shoot and then exported by biomass sorghum. Rio Verde, GO, Brazil. 
Table 3. Accumulation of dry matter (DM) and macro and micronutrients in the shoot part of the biomass sorghum (hybrid Palo Alto 2562), at the harvest stage and as a function of potassium (K) doses. Rio Verde, GO, Brazil.

\begin{tabular}{|c|c|c|c|c|c|c|c|}
\hline \multirow{2}{*}{ Variable } & \multicolumn{5}{|c|}{$\mathrm{K}$ dose $\left(\mathrm{kg} \mathrm{ha}^{-1}\right)$} & \multirow{2}{*}{$\mathrm{F}$} & \multirow{2}{*}{ Equation } \\
\hline & 0 & 70 & 140 & 210 & 280 & & \\
\hline \multirow{3}{*}{ DM } & \multicolumn{7}{|c|}{ - } \\
\hline & 21.83 & 21.43 & 16.30 & 13.87 & 17.30 & $*$ & $y=21.47-0.0237 x$ \\
\hline & & --------- & -1 ----- & --------- & & & \\
\hline $\mathrm{N}$ & 138.7 & 143.3 & 101.7 & 89.67 & 132.7 & $* *$ & $y=149.52-0.5278 x+0.0015 x^{\wedge} 2$ \\
\hline$P$ & 25.67 & 26.67 & 19.67 & 15.33 & 22.67 & $*$ & $y=25.467-0.0247 x$ \\
\hline K & 199.7 & 249.0 & 368.3 & 244.7 & 176.3 & $*$ & $y=189.47+1.8795 x-0.0069 x^{\wedge} 2$ \\
\hline $\mathrm{Ca}$ & 181.3 & 205.7 & 141.0 & 114.3 & 143.7 & $* *$ & $y=190.53-0.2380 x$ \\
\hline $\mathrm{Mg}$ & 69.33 & 74.33 & 50.67 & 39.67 & 50.33 & ns & $y=56.87$ \\
\hline \multirow[t]{2}{*}{$S$} & 14.00 & 14.67 & 9.67 & 8.00 & 7.33 & $* *$ & $y=14.733-0.0286 x$ \\
\hline & & ---------- & & --------- & & & \\
\hline $\mathrm{Cu}$ & 190.7 & 126.0 & 74.33 & 89.33 & 151.3 & $* *$ & $y=195.11-1.4709 x+0.0047^{*} x^{\wedge} 2$ \\
\hline $\mathrm{Fe}$ & 2221 & 3163 & 1839 & 2393 & 1707 & $*$ & $y=2426.9+3.0623 x-0.0201 x^{\wedge} 2$ \\
\hline $\mathrm{Mn}$ & 387.7 & 307.0 & 245.0 & 190.0 & 246.0 & $*$ & $y=395.25-1.7161 x+0.0041 x^{\wedge} 2$ \\
\hline $\mathrm{Zn}$ & 622.0 & 435.7 & 326.3 & 376.3 & 433.3 & $*$ & $y=618.35-3.2605 x+0.0094 x^{\wedge} 2$ \\
\hline B & 315.3 & 155.0 & 281.0 & 243.7 & 250.7 & ns & $y=249.13$ \\
\hline
\end{tabular}

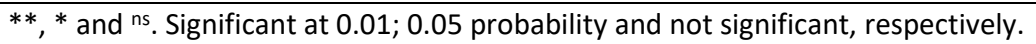

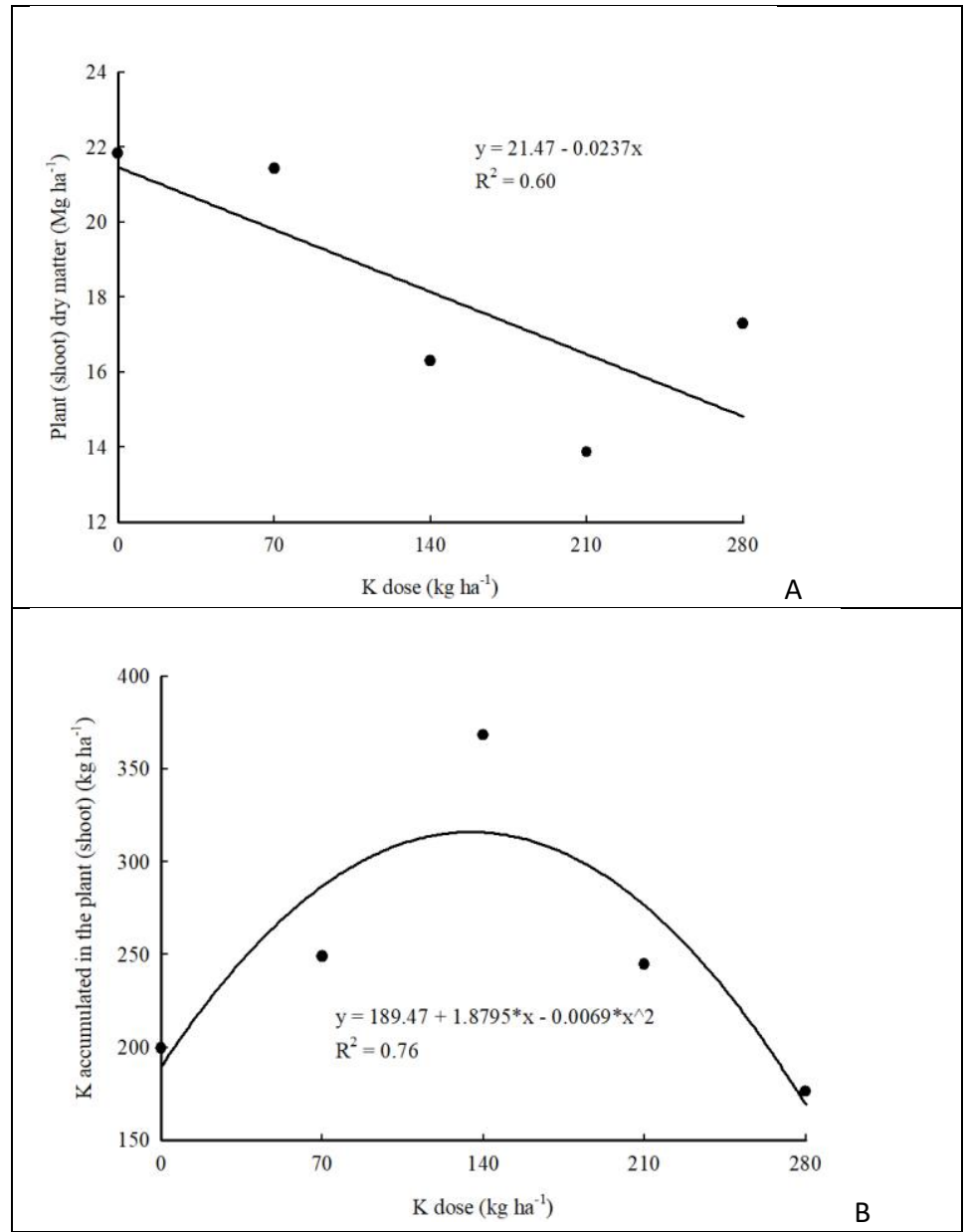

Fig 3. Total shoot dry matter (A) and potassium (K) accumulated in the shoot dry matter (B) of biomass sorghum (hybrid Palo Alto 2562) cultivated in an Oxisol and as affected by K doses. Rio Verde, GO, Brazil. 


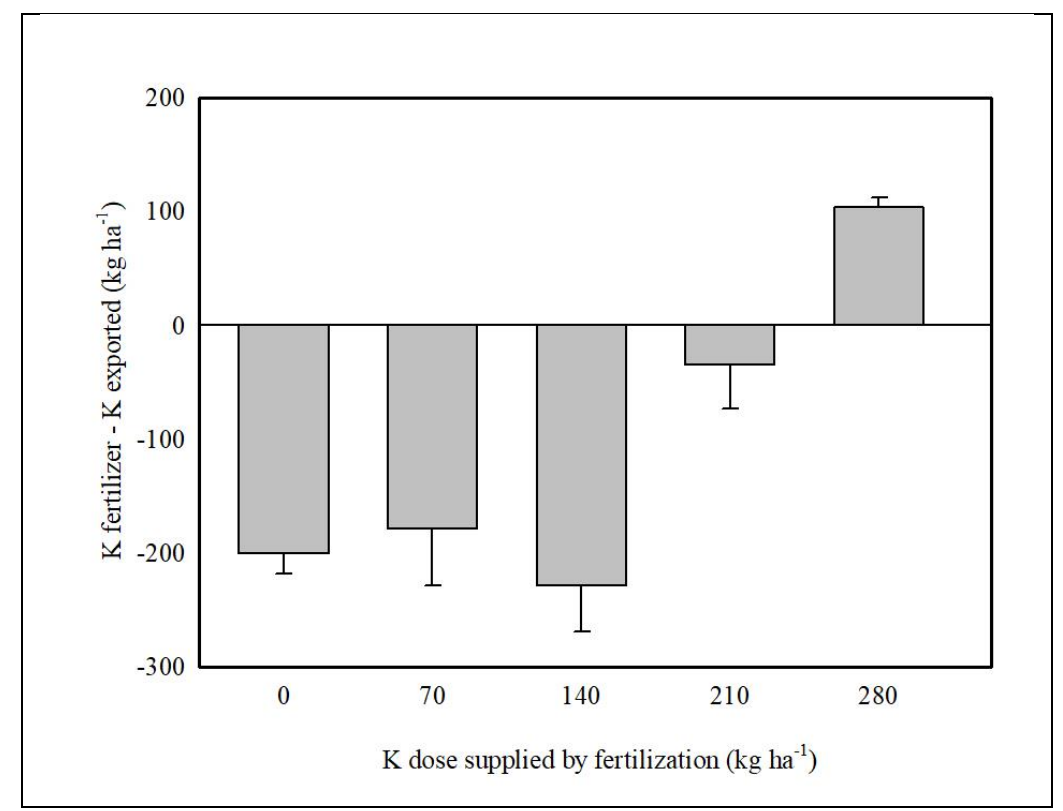

Fig 4. Simple balance between the amount of potassium (K) supplied by the fertilizer (K dose) and the amount of $\mathrm{N}$ accumulated in the shoot and then exported by biomass sorghum. Rio Verde, GO, Brazil.

(Amaducci et al., 2016). The relationship between fertilization need and $\mathrm{N}$ uptake suggests that biomass sorghum requires fertilization above $70 \mathrm{~kg} \mathrm{ha}^{-1} \mathrm{~N}$ (starting from $140 \mathrm{~kg} \mathrm{ha}^{-1}$ ) (Figure 2) to avoid depletion of soil $\mathrm{N}$ levels. This is evident when that the amount of $\mathrm{N}$ accumulated in the shoot part of the plant, even at dose 0 was $67 \mathrm{~kg} \mathrm{ha}^{-1}$ of $\mathrm{N}$ (Figure 1A), possibly resulting from the mineralization of the organic matter present in the soil, which was 31 to $40 \mathrm{~g} \mathrm{dm}^{-3}$ (Table 1 ).

To avoid limitation in biomass production, it is important to provide the total amount of nutrients that plant extracts. This is done mainly through fertilization to avoid withdrawing nutrients from the soil reserves. Besides absorbing nutrients from the fertilizer, the plant can also uptake mineralized $\mathrm{N}$ from the organic matter and occasionally, from the $\mathrm{N}$ biological fixation (Fageria and Baligar, 2005). Thus, fertilization with $140 \mathrm{~kg} \mathrm{ha}^{-1}$ of $\mathrm{N}$ can prevent soil degradation and maintain the sustainability of raw material production for bioenergy production.

Fertilization higher than $70 \mathrm{~kg} \mathrm{ha}^{-1}$ of $\mathrm{N}$ for modern hybrids of biomass sorghum was reported in two-year plantations on typically sandy soil in northern China, where GN-11 biomass sorghum was cultivated under four levels of $\mathrm{N}$ fertilization. It was found that to avoid soil degradation on marginal lands, it was necessary to provide at least one fertilization of $120 \mathrm{~kg} \mathrm{ha}^{-1}$ of $\mathrm{N}$ (Tang et al., 2018). Another study reports that fertilization between 60 and $120 \mathrm{~kg} \mathrm{ha}^{-1}$ of $\mathrm{N}$ could satisfy crop demand since high amounts of $\mathrm{N}$ were extracted from the soil in the control treatment (0) and with $60 \mathrm{~kg} \mathrm{ha}^{-1}$ of $\mathrm{N}$, when sorghum was cultivated in sandy soil with low natural fertility and organic matter content (Ameen et al., 2017). In the South of the USA, to avoid N depletion in the soil, $\mathrm{N}$ fertilization was $183 \mathrm{~kg} \mathrm{ha}^{-1}$ (Hao et al., 2014). Thus, it is evident that the amount of $\mathrm{N}$ required for a satisfactory production of DM from biomass sorghum can vary as a function of cultivated varieties, soil type, and production environment.

In the $\mathrm{K}$ trial, the reduction of DM production with increasing levels of $\mathrm{K}$ (Figure 3B) has already been reported by other authors (Santos et al., 2014), when the variety CMSXS 65, cultivated in Minas Gerais, Brazil, under K doses of 0, 60, 120 and $180 \mathrm{~kg} \mathrm{ha}^{-1}$ produced the highest amount of DM at 0 dose. One of the hypotheses for the present study may be related to the amount of $K$ present in the soil of the experimental area, which at the time of sowing, corresponded to $625.6 \mathrm{~kg} \mathrm{ha}^{-1}$ (Table 1) at $0.0-0.4 \mathrm{~m}$ soil layer.

We observed that the highest estimated $\mathrm{K}$ accumulation in shoot biomass was $316.1 \mathrm{~kg} \mathrm{ha}^{-1}$, at the estimated dose of $134.8 \mathrm{~kg} \mathrm{ha}^{-1} \mathrm{~K}$, so the amount of $\mathrm{K}$ present in the soil was sufficient to nourish the plant. In this context, the high content of $\mathrm{K}$ in the soil may have covered the effect of $\mathrm{K}$ fertilization, even for biomass sorghum, which presents a very high capacity of $\mathrm{K}$ accumulation (Cavalcante et al., 2018). It is important to point out that the maximum accumulation of $\mathrm{K}$ in this study has not produced highest DM production, presenting that the biomass sorghum has a luxury characteristic for $\mathrm{K}$ consumption.

The amount of $K$ available in the soil, and the possible luxury consumption of $\mathrm{K}$ by biomass sorghum, might justifies the absence of crop response to the increase of the $K$ fertilization. However as observed in the present study, the reduction of $\mathrm{DM}$ as a function of fertilization with $\mathrm{K}$ may be related to the relation of bases in the soil.

The effect of $\mathrm{K}$ fertilization on the accumulation of $\mathrm{Ca}$ in the shoot part of the biomass sorghum was similar to the accumulation of DM, because as the dose of $\mathrm{K}$ increased, there was a proportional reduction of $\mathrm{Ca}$ accumulation (Table 3). This behavior may be the evidence of the probable competition between $\mathrm{Ca}$ and $\mathrm{K}$ by exchange sites at the time 
of absorption (Diem and Godbold, 1993), since K absorption is favored in comparison to other cationic species such as $\mathrm{Ca}$ and $\mathrm{Mg}$ (Oliveira et al., 2001). The saturation of $\mathrm{K}$ in the CEC of the soil when we increased the dose from 0 to $280 \mathrm{~kg} \mathrm{ha}^{-1}$ $\mathrm{K}$ varied from 8.04 to $12.15 \%, 3.95$ to $8.65 \%$ and 4.65 to $7.48 \%$ at $00-0.1,0.1-0.2$ and $0.2-0.4 \mathrm{~m}$ layers, respectively. The high $\mathrm{K}$ levels in the soil and the $\mathrm{K}$ saturation in the CEC (> 3\%) (Sousa and Lobato, 2004) of the soil in the present study (even for a condition of acidity and low level of base saturation $(<50 \%)$ may have impaired the absorption of $\mathrm{Ca}$ and, consequently, the production of DM, justifying the deleterious effect of the $\mathrm{K}$ doses on DM production of biomass sorghum. The importance of the $\mathrm{Ca} / \mathrm{K}$ and also $\mathrm{Mg} / \mathrm{K}$ ratio in the soil has already been reported for sweet sorghum. So, the $\mathrm{Ca} / \mathrm{K}$ and also $\mathrm{Mg} / \mathrm{K}$ ratios lower than 7.4 and 0.6 , respectively, may result in yield losses (Rosolem et al., 1984).

The simple balance of $K$ in the system shows that the biomass sorghum needs both the presence of $K$ in the soil and the $\mathrm{K}$ provided by the fertilization, because a quantity of less than $210 \mathrm{~kg} \mathrm{ha}^{-1}$ would not be enough to meet up the crop needs (Figure 4). The high demand of $\mathrm{K}$ for the biomass sorghum has been reported also by other authors. In a 4year experiment in North Carolina, USA, variation in removal of $\mathrm{K}$ by variety Blade ES5200 from 187 to $205 \mathrm{~kg} \mathrm{ha}^{-1}$ of K was reported (Heitman et al., 2017). In Goiás, Brazil, an absorption accumulation curve experiment with the hybrid Palo Alto 2562 found an accumulation of $447 \mathrm{~kg} \mathrm{~K} \mathrm{ha}^{-1}$ for a DM production of $24.4 \mathrm{Mg} \mathrm{ha}^{-1}$ (Cavalcante et al., 2018). For the other nutrients, in the condition of highest $\mathrm{DM}$ productin $\left(21,5 \mathrm{Mg} \mathrm{ha}^{-1}\right.$ with $\left.0 \mathrm{~kg} \mathrm{ha}^{-1} \mathrm{~K}\right)$ the accumulation in the shoot followed the order of: $\mathrm{K} \sim \mathrm{Ca}>\mathrm{N}>\mathrm{Mg}>\mathrm{P}>\mathrm{S}>\mathrm{Fe}>\mathrm{Zn}>\mathrm{Mn}$ $>\mathrm{B}>\mathrm{Cu}$.

\section{Materials and Methods}

\section{Characteristics of experimental area}

The study was conducted at the experimental station of the company Nexsteppe Sementes do Brasil, located in the municipality of Rio Verde, GO, Brazil. According to the classification of Köppen-Geiger, the climate of the region is tropical, with dry season in winter (Aw), average annual rainfall of $1400-1600 \mathrm{~mm}$ and average temperature around 23-24으.

The soil of the experimental area was classified as a Dystrophic Red Latosol (Oxisol) (WRB, 2015) of medium texture ( $45 \%$ of clay). Before the implementation of the trials, the soil was sampled at depths of $0.0-0.1 ; 0.1-0.2$ and $0.2-0.4 \mathrm{~m}$ and analyzed for its main chemical characteristics (Table 1). All analyzes were performed according to the methodologies described by Silva (2009).

\section{Experimental design and treatments}

Two separate experiments were carried out, both in the summer crop year 2015/16, using the hybrid Palo Alto 2562, a modern photoperiod sensitive material from Nexsteppe.
The $\mathrm{N}$ trial was conducted in a randomized block design with four replicates and five $\mathrm{N}$ doses: 0, 70, 140, 210 and $280 \mathrm{~kg}$ ha $^{-1}$. N-urea $(45 \% \mathrm{~N})$ was applied in two steps: $20 \%$ on the furrow after sowing, and $80 \%$ as top dressing, when the plants had 3 fully expanded leaves (V3 - approximately 3 weeks after sowing). A $120 \mathrm{~kg} \mathrm{ha}^{-1}$ of $\mathrm{P}$, as triple superphosphate $\left(41 \% \mathrm{P}_{2} \mathrm{O}_{5}\right.$ and $\left.12 \% \mathrm{Ca}\right)$ was also used in the fertilization and distributed in the sowing furrow, and $140 \mathrm{~kg}$ $\mathrm{ha}^{-1}$ of $\mathrm{K}$ was applied as top dressing as potassium chloride $\left(\mathrm{KCl}, 60 \% \mathrm{~K}_{2} \mathrm{O}\right)$.

Similarly, the $\mathrm{K}$ trial was conducted in a randomized block design with four replicates and five doses of $\mathrm{K}: 0,70,140$, 210 and $280 \mathrm{~kg} \mathrm{ha}^{-1}$. Potassium was applied manually as $\mathrm{KCl}$ and in two steps: $40 \%$ on the furrow after sowing and $60 \%$ as top dressing, at the same time of $\mathrm{N}$ fertilization (V3). In the fertilization, there was also $120 \mathrm{~kg} \mathrm{ha}^{-1}$ of $\mathrm{P}$, as triple superphosphate and distributed in the sowing furrow, and $140 \mathrm{~kg} \mathrm{ha}^{-1}$ of $\mathrm{N}$-urea applied as top dressing.

The experimental plots consisted of four rows $5 \mathrm{~m}$ long and $0.50 \mathrm{~m}$ apart. The adoption of the spacing of $0.50 \mathrm{~m}$ considered the results obtained by May et al. (2015). The useful plot was composed by the two central lines, excluding $1 \mathrm{~m}$ from each end. Sowing was carried out on November 04, 2015 with a mechanical seeder for no-till, equipped with a vacuum system, aiming a population of 110 to 120 thousand plants $\mathrm{ha}^{-1}$. For insect control, triflumurom, flubendiamide and lambda-cyhalothrin were applied at 10, 26 and 28 days after planting (DAP), and the herbicide atrazine at 26 DAP for weed control.

\section{Evaluations}

The evaluations were carried out at the same time of the harvest, which took place on March 08, 2016, considering only the plants from the useful plot. In the field, plant height (measured, in meters, from the soil surface to the tip of the grain panicle with the aid of a ruler) and the diameter of the stem (diameter, in $\mathrm{mm}$, measured with the aid of a digital caliper in the third node of the plant) was measured in five plants per plot.

Five plants of each plot were then cut close to the surface of the soil, crushed in a forage harvester and then weighed. From the resulting material, a sample of approximately 200 g was collected, weighed and taken to a drying oven with forced air circulation at $65{ }^{\circ} \mathrm{C}$ until constant mass. The samples were weighed again for moisture correction and then the values were converted to $\mathrm{kg} \mathrm{ha}^{-1}$ to obtain the dry matter.

The samples were analyzed for $\mathrm{N}, \mathrm{P}, \mathrm{K}, \mathrm{Ca}, \mathrm{Mg}, \mathrm{S}, \mathrm{Cu}, \mathrm{Fe}, \mathrm{Mn}$, $\mathrm{Zn}$ and $\mathrm{B}$, according to the methodologies described by Silva (2009). With the content of these nutrients and the shoot dry matter, the export of nutrients was calculated in $\mathrm{kg} \mathrm{ha}^{-1}$.

\section{Statistical analysis}

Data were submitted to analysis of variance. Once the treatment effect was detected by the $F$ test, the results were submitted to polynomial multiple regression analysis (Ferreira, 2011). The simplified balance of nutrients $\mathrm{N}$ and $\mathrm{K}$ 
was calculated by subtracting the quantity exported by the plant from the applied doses of the element.

\section{Conclusions}

The hybrid of biomass sorghum Palo Alto 2562, cultivated in an Oxisol, positively responds (in terms of dry matter production) to $\mathrm{N}$ fertilization up to the dose of $280 \mathrm{~kg} \mathrm{ha}^{-1}$, requiring at least $140 \mathrm{~kg} \mathrm{ha}^{-1} \mathrm{~N}$ in order to avoid depletion of $\mathrm{N}$ levels in the soil. The hybrid of biomass sorghum Palo Alto 2562 has a high absorption capacity of $\mathrm{K}$, which is the most absorbed nutrient by the plant. Part of the accumulated $\mathrm{K}$, however, seems to be associated with a luxurious absorption characteristic of the plant. In conditions of an Oxisol with high level of $K$ and high $K$ saturation in the CEC, the $K$ fertilization may negatively affect the dry matter production of biomass sorghum hybrid Palo Alto 2562, so the best option would be to refrain $\mathrm{K}$ as fertilizer.

\section{Acknowledgements}

To CAPES (Coordination for the Improvement of Higher Education Personnel), by granting the scholarship to the $1^{\text {st }}$ author to the company Nexsteppe Sementes do Brasil for the technical and financial support in the trials and to the IF Goiano for the support in translating and publishing this paper.

\section{References}

Almeida LGF, Parrella RAC, Simeone MLF, Ribeiro PCO, Santos AS, Ribeiro PCO, Santos AS, Costa ASV, Guimarães AG, Shaffert, RE (2019) Composition and growth of sorghum biomass genotypes for ethanol production. Biomass Bioenerg. 122:343-348.

Amaducci S, Colauzzi M, Battini F, Fracasso A, Perego A (2016) Effect of irrigation and nitrogen fertilization on the production of biogas from maize and sorghum in a water limited environment. Eur $\mathrm{J}$ Agron. 76:54-65.

Ameen A, Yang X, Chen F, Tang C, Du F, Fahad S, Xie GH (2017) Biomass yield and nutrient uptake of energy sorghum in response to nitrogen fertilizer rate on marginal land in a semi-arid region. Bioenerg Res. 10(2):363-376.

Castoldi G, Costa MSSM, Costa LAM, Pivetta LA, Steiner F (2011) Sistemas de cultivo e uso de diferentes adubos na produção de silagem e grãos de milho. Acta Sci-Agron. 33(1):139-146.

Cavalcante TJ, Castoldi G, Rodrigues CR, Nogueira MM, Albert, AM (2018) Macro and micronutrients uptake in biomass sorghum. Pesqui. Agropecu. Trop. 48(4):364-373.

Diem B, Godbold DL (1993) Potassium, calcium and magnesium antagonism in clones of Populus trichocarpa. Plant Soil. 155(1):411-414.

Fageria NK, Baligar VC (2005). Enhancing nitrogen use efficiency in crop plants. Adv Agron. 88:97-185.

Ferreira DF (2011) Sisvar: a computer statistical analysis system. Ciênc Agrotec. 35(6):1039-1042.

Hao B, Xue Q, Bean BW, Rooney WL, Becker JD (2014) Biomass production, water and nitrogen use efficiency in photoperiodsensitive sorghum in the Texas High Plains. Biomass Bioenerg. 62:108-116.
Heitman AJ, Castillo MS, Smyth TJ, Crozier CR, Wang Z, Heiniger RW, Gehl, RJ (2017) Nitrogen fertilization effects on yield and nutrient removal of biomass and sweet sorghum. Agron J. 109(4):13521358.

Júlio GMF, Santos FC, Passos AMA, Albuquerque Filho MR, Simeone MLF (2016) Manejo da adubação potássica de cobertura no sorgo biomassa. Paper presented at the 11th PIBIC/CNPQ scientific initiation seminar, Embrapa Milho e Sorgo, Sete Lagoas, 1-5, 2016.

May A, Souza VF, Gravina GA, Fernandes PG (2015) Plant population and row spacing on biomass sorghum yield performance. Cienc. Rural. 46(3):434-439.

Meki MN, Ogoshi RM, Kiniry JR, Crow SE, Youkhana AH, Nakahata MH, Littlejohn K (2017) Performance evaluation of biomass sorghum in Hawaii and Texas. Ind Crops Prod. 103:257-266.

Oliveira FA, Carmello QAC, Mascarenhas, HAA (2001) Disponibilidade de potássio e suas relações com cálcio e magnésio em soja cultivada em casa-de-vegetação. Sci Agri. 58(2):329-335.

Olson SN, Ritter K, Medley J, Wilson T, Rooney WL, Mullet JE (2013) Energy sorghum hybrids: Functional dynamics of high nitrogen use efficiency. Biomass Bioenerg. 56:307-316.

Pannacci E, Bartolini, S (2016) Evaluation of sorghum hybrids for biomass production in central Italy. Biomass Bioenerg. 88:135141.

Rego TJ, Nageswara Rao V, Seelinf B, Pardhasaradhi G, Kumar Rao JVDK (2003) Nutrient balances - a guide to improving sorghum and groundnut-based dryland cropping systems in semi-arid tropical India. Field Crop Res. 81(1):53-68.

Rooney WL, Blumenthal J, Bean B, Mullet JE (2007) Designing sorghum as a dedicated bioenergy feedstock. Biofuel Bioprod Bior. 1(2):147-157.

Rosolem CA, Machado JR, Brinholi O (1984) Efeito das relações $\mathrm{Ca} / \mathrm{Mg}, \mathrm{Ca} / \mathrm{K}$ e $\mathrm{Mg} / \mathrm{K}$ do solo na produção de sorgo sacarino. Pesqui. agropec. bras. 19(12): 1443-1448.

Santos FC, Albuquerque Filho MR, Resende, AV, Oliveira AC, Gomes TC, Oliveira MS (2014) Adubações nitrogenada e potássica no sorgo biomassa: produtividade e qualidade de fibra. Rev Bras Milho Sorgo. 13(1):1-13.

Santos FC, Albuquerque Filho MR, Resende AV, Oliveira AC, Oliveira MS, Gomes TC (2015) Adubação nitrogenada e potássica na nutrição e na extração de macronutrientes pelo sorgo biomassa. Rev Bras Milho Sorgo. 14(1):10-22.

Silva FC (ed) (2009) Manual de análises químicas de solos, plantas e fertilizantes, 2nd edn. Embrapa, Brasília DF.

Silva MJ, Carneiro PCS, Carneiro JES, Damasceno CMB, Parrella NNLD, Pastina MM, Simeone MLF, Schaffert RE, Parrella RAC (2018) Evaluation of the potencial of lines and hybrids of biomass sorghum. Ind Crops Prod.125(1):379-385.

Sousa DMG, Lobato E (ed) (2004) Cerrado: correção do solo e adubação, 2nd edn. Embrapa, Brasília DF.

Tang C, Yang X, Chen X, Ameen A, Xie G (2018) Sorghum biomass and quality and soil nitrogen balance response to nitrogen rate on semiarid marginal land. Field Crop Res. 215(2):12-22.

Wight JP, Hons FM, Storlien JO, Provin TL, Shahandeh H, Wiedenfeld RP (2012) Management effects on bioenergy sorghum growth, yield and nutrient uptake. Biomass Bioenerg. 46:593-604.

World reference base (WRB) for soil resources 2014, update 2015. International soil classification system for naming soils and creating legends for soil maps. Food and Agriculture Organization of the United Nations. Rome, IUSS/ISRIC/FAO, 2015. 192p. (World Soil Resources Reports, No. 106). 